\title{
Malaria at Forest Areas in South Kalimantan, Indonesia: Risk Factors and Strategies for Elimination
}

\author{
Istiana Istiana ${ }^{1,2}$ (D), Usman Hadi $^{3 *}(\mathbb{D})$, Yoes Prijatna Dachlan ${ }^{4}$ (D) Heny Arwati $^{4}$ (D) \\ ${ }^{1}$ Doctoral Student of Medicine, Medical Faculty, Universitas Airlangga, Surabaya, Indonesia; ${ }^{2}$ Department of Microbiology and \\ Parasitology, Faculty of Medicine, Universitas Lambung Mangkurat, Banjarmasin, Indonesia; ${ }^{3}$ Department of Internal Medicine, \\ Faculty of Medicine, Universitas Airlangga, Surabaya, Indonesia; ${ }^{4}$ Department of Parasitology, Faculty of Medicine, Universitas \\ Airlangga, Surabaya, Indonesia
}

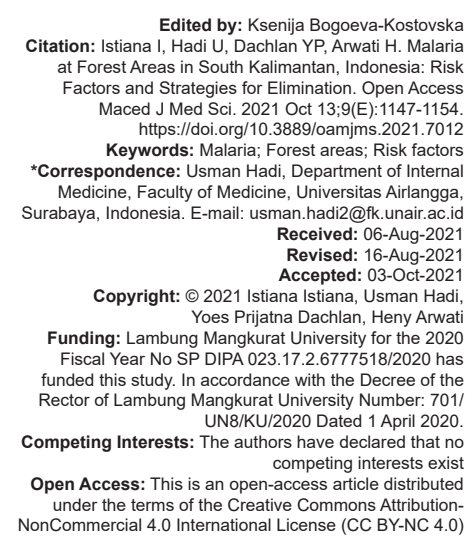

Introduction

Malaria cases in Southeast Asia from 2000 to 2019 also decreased from 23 million to 6.3 million from 2010 to 2019 . This $73 \%$ decline was also followed by a decrease in case incidence, from 18 to 4 cases from 2000 to 2019 [1]. This reduction in malaria cases is related to the success of various programs that have been implemented such as distribution of long-lasting insecticide treated nets, use of indoor residual spraying, wide coverage of diagnosis using microscopes and rapid diagnostic tests (RDTs), and easy access to treatment [2]. Even so, there is still a high burden in managing malaria, including the difficulty of eliminating malaria in remote areas which are the largest contributor to current cases [3].

Data from the Ministry of Health show that the annual parasite incidence (API) for Indonesia in $2020=$ 0.87 and $2019=0.93$; for South Kalimantan in $2019=$
0.22; and for Tanah bumbu $2019=0.31$. There are 96 villages in the red category across 9 districts, one of which is Tanah Bumbu District with an API of 0.54 in 2016, 0.49 in 2017, and 0.17 in 2018. Although there has been a significant decrease in malaria cases in the last 3 years, still found red category villages in Kusan Hulu and Mantewe Districts. The villages with high case incidence in Kusan Hulu and Mantewe Districts are mostly located in remote areas with secondary forest areas and on the edge of the forest [4]. Forests are one of the ecosystems that can support the formation of an environment where malaria vectors can reproduce [5], [6], [7]. Malaria in this area is the biggest contributor to malaria prevalence in South Kalimantan. Barriers to eradicating malaria in this area including difficulty road access, minimal health facilities, inadequate infrastructure, high population mobility to the forest due to socio-economic factors, and a lack of knowledge about malaria transmission [5].

The environment is an important factor in malaria transmission [5]. As a human and mosquito 
vector habitat, the influence on human behavior and the reproduction of mosquitoes is very large [7]. Anopheles mosquitoes that live in certain environments must have a habit of biting humans and have a longlife cycle. This is needed by the parasite to complete its life cycle to produce an infective form (sporozoite) and transmit it to humans. Environmental temperature also affects the speed of plasmodium development in the mosquito's body, the intensity of malaria transmission increases after the rainy season which is associated with an increase in the mosquito population [8], [9], [10].

Other environmental factors such as the existence of breeding places for Anopheles mosquitoes (rivers, swamps, ponds, rainwater puddles), and changes in forest function affect malaria transmission significantly [2], [3], [5]. The existence of standing water can be a source of breeding for mosquitoes, especially close to residential areas [3]. Changes in forest function also affect socio-economic changes that have an impact on the incidence of malaria. For example, land clearing due to logging activities is associated with unstable conditions, including population mobility, exposure to non-immune people, and housing conditions conducive to transmission [11].

Several studies have shown an increase in the incidence of malaria in areas experiencing deforestation, especially in Africa and Latin America but decreasing in Asia. Deforestation leads to an increase in ambient temperature [12], more sunshine and puddle [13], which causes an increase in the life cycle of mosquitoes [14], the rate of growth and pupa formation is faster [15], longer survival time [16], and the high frequency of mosquito bites [17], [18].

To support the elimination program in 2030 , it is necessary to carry out research related to the factors that influence the prevalence of malaria in the population in endemic areas in South Kalimantan, especially the housing and environmental conditions factors. Understanding the risk factors which can increase the risk of malaria in individuals at forest area will enable more effective use for controlling the disease. The identification of risk factors will provide information about local malaria epidemiology and usefull for making appropriate and effective malaria eradication program policies in this area.

\section{Methods}

\section{Study area and population}

The study was conducted within Kusan Hulu District in Tanah Bumbu Region of South Kalimantan Province (20 $57^{\prime}$ ' " LS - 30³8' 24" LS dan 1150 24' 0" BT - 1150 49' 12" BT) [19]. The population of that district was 19.861. We did a descriptive analysis and conducted a cross-sectional study to identify environmental factors associated with malaria. Data were collected in September 2020, the early rainy season. Malaria transmission usually peaks during the rainy season, but in this district incidence of malaria is considered high throughout the year. All participating respondents, in this study, were men and women aged 16 until 60 years and resided in two villages (Batu Bulan and Batu Paha). Sampling was done using simple random sampling of all residents who met the inclusion criteria. Villages were selected based on criteria: endemic area of malaria with annual parasite index in 2018 was more than 1\%. The research was conducted in selected areas involving the health office, the malaria program manager at the local public health center, and the village authorities. Researchers and village officials will visit every house to conduct interviews, collect venous blood, and observe the surrounding environment.

\section{Variables}

We used a standardized questionnaire from kinds of literature to collect data from participants. The questionnaire was administered by trained interviewers to collect data on patient age, gender, the residence of villages, education, occupation, ethnicity, and house condition including roof condition, walls, having a house ceiling, using a mosquito wire screen, and having animal cage. This research didn't do vector survey, only on prevalence of malaria and risk factor in human and environment.

\section{Malaria diagnostic}

The venous blood that has been taken will be dropped onto an object-glass to make thin and thick blood preparations and measured with RDT. Microscopic identification of malaria will be carried out at the Parasitology Laboratory at Faculty of Medicine Universitas Lambung Mangkurat.

\section{RDT examination}

Qualitative detection of Plasmodium spp antigens, Histidine-rich protein II (HRP2) expressed by Plasmodium falciparum or parasite lactatedehydrogenase ( $\mathrm{pLDH}$ ) metabolic enzyme, expressed by all species of Plasmodium spp. (Pf/pan) using lateral flow immunochromatography devices containing antigen-specific monoclonal antibodies from mice. Using a capillary tube $(5 \mu \mathrm{L})$, the whole blood sample is collected until it reaches the black line and transferred to the cassette sample well. Four drops of diluent are added vertically for testing in the well. The result is read after 15-30 min. A result is considered negative if a color band is observed in line " $C$;" it is $P$. falciparumpositive if 2 color bands are observed inline "P.f" and $\mathrm{C}$, or 3 color bands in lines P.f, "Pan" and C; the test is 
considered positive for another species of Plasmodium (Plasmodium vivax, Plasmodium malariae, Plasmodium ovale) if 2 color bands are observed inline Pan and C. A color band should always be observed inline C; otherwise, it is considered as an invalid result and the test must be repeated [19], [20].

The kind of RDT in this study was:

SD Bioline Malaria Ag Pf/Pv. Manufactured by Standard Diagnostic Inc

Specification: Detect HRP2 Ag specific to $P$. falciparum and pLDH specific to $P$. vivax

Differentiate mono infection and mix infection

Using whole blood

Sensitivity: $\mathrm{Pf}=99.7 \%, \mathrm{Pv}=95.5 \%$

Specifiicity $=99.5 \%$

\section{Microscopic diagnosis}

Thick and thin blood smears were made on the same slide at the same time, air-dried for one night, and fixation with methanol. The slides were transported to the parasitology laboratory, the Faculty of Medicine Banjarmasin. The slides were stained with 3\% Giemsa for $10 \mathrm{~min}$ and screened for the presence of plasmodium infections. The slides were read by a microscopist who was blinded to the individual RDT results. A slide was classified as negative if no Plasmodium asexual forms or gametocytes were found after counting 500 WBCs. Thin blood films were examined for Plasmodium species by counting the number of parasites per 5000 red blood cells. For quality control purposes, a second experienced microscopist randomly selected $5 \%$ of the slides for re-examination [21], [22].

\section{Data processing and analysis}

Data were checked for completeness and consistency and entered into an SPSS 25.0 (SPSS Inc) database. Descriptive analyses were conducted frequency with percentages for categorical variables. Both Chi-square $\left(\chi^{2}\right)$ test and multivariable logistic regression were performed to identify factors associated with the prevalence of malaria. An error probability $(p<0.05)$ was considered statistically significant. Data were presented using odds ratio (OR).

\section{Results}

\section{Sociodemographic characteristics}

A total of 107 participants were included in this study and all of them living in Batu Bulan and Batu
Paha villages [23]. Sociodemographic characteristic of the subjects are in Table 1.

Table 1: Below presents a summary of the sociodemographic characteristics of the subject population in this study

\begin{tabular}{ll}
\hline Variables & Frequency $(\mathrm{n}=107)$ \\
\hline Age & \\
$<25$ & $35(32.7 \%)$ \\
$>25$ & $72(67.3 \%)$ \\
Gender & $69(64.5 \%)$ \\
$\quad$ Male & $38(35.5 \%)$ \\
Female & \\
Ethnicity & $102(95.3 \%)$ \\
Banjar & $5(4.7 \%)$ \\
Dayak & \\
Villages & $69(64.5 \%)$ \\
Batu Bulan & $38(35.5 \%)$ \\
Batu Paha & \\
Education & $52(48.6 \%)$ \\
$\quad$ No school & $55(51.4 \%)$ \\
School & $79(73.8 \%)$ \\
Occupation & $28(26.2 \%)$ \\
$\quad$ Forest workers & \\
Non-Forest workers &
\end{tabular}

\section{Household characteristic factors}

Household characteristic factors were identified and show in Table 2.

Table 2: House hold characteristic factors

\begin{tabular}{ll}
\hline Variables & Frequency $(\mathrm{n}=107)$ \\
\hline Wall & \\
Open & $83(77.6 \%)$ \\
Closed & $24(22.4 \%)$ \\
Have a house ceiling & \\
$\quad$ No & $84(78.5 \%)$ \\
Yes & $23(21.5 \%)$ \\
Roof & $15(14 \%)$ \\
$\quad$ Plastic & $92(86 \%)$ \\
Tin roof & \\
Mosquito wire screen & $93(86.9 \%)$ \\
No & $14(13.1 \%)$ \\
Yes & \\
Body water (puddles) & $38(35.5 \%)$ \\
Yes & $69(64.5 \%)$ \\
No & $15(14 \%)$ \\
Animal Cage & $92(86 \%)$ \\
$\quad$ Yes & \\
No & \\
\hline
\end{tabular}

\section{Prevalence of malaria parasites in this study population}

Thirty-eight (35.5\%) participants in this study had RDT confirmed malaria positivity but just only 19 participants $(17.75 \%)$ had microscopically confirmed malaria parasites in their blood sample. The most of Plasmodium species in RDT were mixed of $P$. falciparum and $P$. vivax 21 (19.6\%), followed by $P$. falciparum 9 (8.4\%) and $P$. vivax 8 (7.5\%). However, in microscopic examination, the dominant Plasmodium species were $P$. falciparum 9 (47.36\%), followed by $P$. vivax $5(26.32 \%)$ and $5(26.32 \%)$ showed mixed infections of $P$. falciparum and $P$. vivax (Table 3 ). In this research, P.Knowlesi was not found (based on PCR examination). The report of PCR examination not include in this paper.

Difference between microscopic and RDT result was caused by less of parasite number in blood, so it could not detected in microscopic examination. High prevalence of malaria based on RDT was caused 
by HRP2 $P$. falciparum antigen and pLDH $P$. vivax could maintain until some times although already cured. In this research, respondents were infected already by plasmodium and cured before blood examination but still could be detected by RDT.

Table 3: Prevalence of malaria among the study participants

\begin{tabular}{llllll}
\hline $\begin{array}{l}\text { Mode of } \\
\text { examinations }\end{array}$ & $\begin{array}{l}\text { Number of } \\
\text { Participans }\end{array}$ & $\begin{array}{l}\text { Number } \\
\text { positive (\%) }\end{array}$ & $\begin{array}{l}\text { Positive for } \\
\text { Plasmodium } \\
\text { falciparum (\%) }\end{array}$ & $\begin{array}{l}\text { Positive for } \\
\text { Plasmodium } \\
\text { vivax }(\%)\end{array}$ & $\begin{array}{l}\text { Positive for } \\
\text { mixed (\%) }\end{array}$ \\
\hline $\begin{array}{l}\text { Rapid } \\
\text { Diagnostic }\end{array}$ & 107 & $38(35.5 \%)$ & $9(23.68 \%)$ & $8(21.05 \%)$ & $21(55.27 \%)$ \\
$\begin{array}{l}\text { Test } \\
\text { Microscopic }\end{array}$ & 107 & $19(17.75 \%)$ & $9(47.36 \%)$ & $5(26.32 \%)$ & $5(26.32 \%)$ \\
\hline
\end{tabular}

\section{Factors associated with malaria positivity}

The malaria prevalence data used to determine the relationship between risk factors and malaria incidence were based on microscopic examination. The potential risk factors associated with the incidence of malaria in this study were age, the village of residence, occupation, condition of the walls of the house, the type of roof used, and the presence or absence of an animal cage (Table 4).

Table 4: Risk factors analysis for malaria positivity detected by LM using Chi-square test

\begin{tabular}{|c|c|c|c|c|}
\hline Variables & Negative & Positive & OR $(95 \% \mathrm{Cl})$ & $\mathrm{p} \mathrm{(95 \%} \mathrm{Cl)}$ \\
\hline \multicolumn{5}{|l|}{ Age } \\
\hline$<25$ years & $68.58 \%(24 / 35)$ & $31.2 \%(11 / 35)$ & 2.289 & $0.010^{*}$ \\
\hline$>25$ years & $88.88 \%(64 / 72)$ & $11.12 \%(8 / 72)$ & & \\
\hline \multicolumn{5}{|l|}{ Gender } \\
\hline Male & $81.16 \%(56 / 69)$ & $18.84 \%(13 / 69)$ & & 0.693 \\
\hline Female & $84.21 \%(32 / 38)$ & $15.79 \%(6 / 38)$ & & \\
\hline \multicolumn{5}{|l|}{ Ethnicity } \\
\hline Banjar & $82.35 \%(84 / 102)$ & $17.65 \%(18 / 102)$ & & 0.893 \\
\hline Dayak & $80 \%(4 / 5)$ & $20 \%(1 / 5)$ & & \\
\hline \multicolumn{5}{|l|}{ Villages } \\
\hline Batu Bulan & $76.81 \%(53 / 69)$ & $23.19 \%(16 / 69)$ & 3.522 & $0.048^{*}$ \\
\hline Batu Paha & $92.10 \%(35 / 38)$ & $7.9 \%(3 / 38)$ & & \\
\hline \multicolumn{5}{|l|}{ Education } \\
\hline No School & $78.85 \%(41 / 52)$ & $21.15 \%(11 / 52)$ & & 0.371 \\
\hline School & $85.45 \%(47 / 55)$ & $14.55 \%(8 / 55)$ & & \\
\hline \multicolumn{5}{|l|}{ Occupation } \\
\hline Forest workers & $77.2 \%(61 / 79)$ & $22.8 \%(18 / 79)$ & 6.380 & $0.022^{*}$ \\
\hline Non forest workers & $96.4 \%(27 / 28)$ & $3.6 \%(1 / 28)$ & & \\
\hline \multicolumn{5}{|l|}{ Wall } \\
\hline Open & $78.3 \%(65 / 83)$ & $21.7 \%(18 / 83)$ & 5.205 & $0.048^{*}$ \\
\hline Closed & $95.8 \%(23 / 24)$ & $4.2 \%(1 / 24)$ & & \\
\hline \multicolumn{5}{|l|}{ Have a house ceiling } \\
\hline No & $79.8 \%(67 / 84)$ & $20.2 \%(17 / 84)$ & & 0.199 \\
\hline Yes & $91.3 \%(21 / 23)$ & $8.7 \%(2 / 23)$ & & \\
\hline \multicolumn{5}{|l|}{ Roof } \\
\hline Plastic & $60 \%(9 / 15)$ & $40 \%(6 / 15)$ & 2.831 & $0.015^{*}$ \\
\hline Tin roof & $85.9 \%(79 / 92)$ & $14.1 \%(13 / 92)$ & & \\
\hline \multicolumn{5}{|l|}{ Mosquito wire screen } \\
\hline No & $80.6 \%(75 / 93)$ & $19.4 \%(18 / 93)$ & & 0.265 \\
\hline Yes & $92.9 \%(13 / 14)$ & $7.1 \%(1 / 14)$ & & \\
\hline \multicolumn{5}{|l|}{ Body water (puddles) } \\
\hline Yes & $76.3 \%(29 / 38)$ & $23.7 \%(9 / 38)$ & & 0.234 \\
\hline No & $85.5 \%(59 / 69)$ & $14.5 \%(10 / 69)$ & & \\
\hline \multicolumn{5}{|l|}{ Animal cage } \\
\hline Yes & $60 \%(9 / 15)$ & $40 \%(6 / 15)$ & 6.292 & $0.015^{\star}$ \\
\hline No & $85.9 \%(79 / 92)$ & $14.1 \%(13 / 92)$ & & \\
\hline
\end{tabular}

Multivariate analyzes was done to know fit model of this data. The result was 0.792 ; this data could be analyzed. Determinant coefficient was 0.266 , it meant the variability of malaria could be explained by independent variables $26.6 \%$ ( $73.4 \%$ was caused by other factors). Fitting moder information was 0.002 ; there was significant effect from independent variables to dependent variable.

Multinomial logistic regression showed people who work in the forest area had possibility to get malaria
5,195 more than people who work not in the forest area (Confidence interval [Cl] 0.572-47.169). People who lived in a house that not standardized to get malaria was $4.677(\mathrm{Cl}=0.533-41.079)$. People who lived in unstandardized roof house had possibility to get malaria $3.025(\mathrm{Cl}=0.761-12.024)$. People under 25-years-old had risk to get malaria $2.526(\mathrm{Cl}=0.804-7939)$.

Batu Bulan is a village in the middle of a forest inhabited by people who work as forest workers. Occupation is one of the factors that influence the incidence of malaria in this study where participants who work in the forest both as gold miners and woodcutters get malaria by $22.8 \%$ compared to participants who work not in the forest $(p<0.05$; OR = 6.380).

Likewise, the condition of the roof of the house made of plastic is a risk factor for the incidence of malaria, where in this study it was found that $40 \%$ of participants were infected with malaria from all participants whose roofs were made of plastic compared to roofs made of zinc $(p<0.05$; OR $=2.831)$. A roof made of plastic is a roof that is not permanent, easily damaged due to sun exposure and heavy rain, so the possibility of mosquitoes getting into and biting the occupants is very large. Another factor that affects the prevalence of malaria, in this study, is the presence of animal sheds around the house, where in this study it was found that $40 \%$ of participants were infected with malaria compared to participants who did not have an animal pen, which was only $14.1 \%$ ( $p<0.05$; OR = 6.292). The type of animal cage owned by residents is a chicken coop and this cage is placed between 2 and 3 meters from the house.

Sociodemographic factors that were not directly related significantly in this study were gender, race, and education. Although it was not directly related statistically $(p>0.05)$, it appears descriptively that the incidence of malaria in men was more $(18.84 \%)$ compared to women $(15.79 \%)$. Most of the participants were Banjarese (95.3\%) who $17.65 \%$ had malaria parasites in their blood based on microscopic examination. In contrast to the Dayak tribe, only $4.7 \%$ of all participants, but $20 \%$ of them had malaria parasites in their blood $(p>0.05)$. The education category of participants in this study was almost the same between those who did not go to school $(48.6 \%)$ and those who were in school (51.4\%). Most of those who attend school are elementary school graduates (72.9\%), while junior and senior high school graduates are still very few (18.1\% and $9 \%$, respectively). As many as $21.15 \%$ of participants who did not go to school were found malaria parasites in their blood, while in school participants only $14.55 \%$ were found. Although there were differences between participants who went to school and those who did not go to school, statistically there was no significant relationship ( $p>0.05)$. Several factors related to the condition of the house that were not related to the incidence of malaria in this study were the presence or absence of a ceiling in the 
house, installing mosquito nets, and the presence or absence of standing water around the house. As many as $78.5 \%$ of the participants did not have a ceiling in their place, $86.9 \%$ did not install mosquito netting, and only a fraction (35.5\%) had standing water around their house. About $20.2 \%$ of participants with a house without a ceiling found malaria parasites in their blood, while in participants with a house with a ceiling only $8.7 \%$ had parasites found. As many as $19.4 \%$ of participants who did not install mosquito wires found parasites in the blood, while only $7.1 \%$ of participants who installed mosquito wires were positive for malaria. In the participants with standing water at home, $23.7 \%$ were found to be positive for malaria, while the participants who did not have stagnant water were only $14.5 \%$.

\section{Discussion}

$P$. falciparum was the most common species in this study, with about $47.37 \%$ of all malaria-positive, followed by $P$. vivax and mixed infections. This study has similarities with the research of Nath and Mwchahary in India which showed that the prevalence of $P$. falciparum was still high in forest and non-forest areas [8]. The high of $P$. falciparum infection indicates a risk of serious complications. However, falciparum malaria can be treated quickly using an artemisinin regimen. In contrast to $P$. vivax infection, this is usually more difficult to treat because it has a hypnozoite stage in the liver [24]. To kill this hypnozoite stage, treatment with Primakuin is required for a longer oral administration time and potentially causes low drug adherence rates. P.vivax also can transmit malaria despite the low parasite density in the blood. Mixed infections ( $P$. vivax and $P$. falciparum) that are persistent and usually asymptomatic are common in areas within low malaria transmission. Infections with low-density parasitemia can progress to high-density infections at other times, and this tends to maintain the level of endemicity [25], [26], [27].

The most of the participants with positive malaria parasites in this study were asymptomatic. It is probably a consequence of acquired immunity due to the high transmission intensity in this area. People with asymptomatic malaria have the potential to spread and sustain transmission if they are not detected and given treatment. This research was conducted at the beginning of the rainy season, which theoretically is not the peak of malaria transmission. It is possible to find more cases during the peak season of transmission at the end of the rainy season. Therefore, it is necessary to carry out regular surveillance to detect and monitor asymptomatic malaria to prevent wider transmission [25], [26].

Batu Bulan and Batu Paha Villages are the remote villages in Tanah Bumbu Regency. These two villages are on the border with Banjar Regency. The most of the people who live in this village are Banjarese. Another tribe that also exists is the Dayak tribe, although the numbers are small. They have lived side by side for a long time, making physical ethnic separation extremely difficult. Ethnically, there is no significant difference in the incidence of malaria between the two tribes. Apart from being mixed, the factor of the same occupation as forest workers was the reason. There was no significant difference in the prevalence of malaria based on ethnicity. The study by Achidi et al. in Cameroon shows that there are differences in the number of parasitemia in 3 different tribes even though they live in the same area. This difference is due to a genetic variation in the immune response to a pathogen [28]. Some tribes have a certain susceptibility to malaria, while others may be more resistant to infection. However, the research also shows that this difference is due to more pathogenic factors than to immune factors [29].

Activities in the forest are one of the risk factors for malaria transmission in The Kusan Hulu District. Forest workers were 4,332 times more likely to be infected with malaria through the bite of Anopheles sp. The types of work they do are gold miners and woodcutters. Gold mining in these forest areas starts in the morning around 04.00 . This is the reason why gold miners are more frequently infected with malaria. This result was have similarities with the research of Sulistyowati and Fitriani in Kulon Progo Indonesia that the risk occupation for malaria was miner, carpenter, wood cutter, and all outdoor work until the late of night [30]. Similarly, Sandfort et al. showed that working in the forest is a risk factor for malaria transmission in Cambodia 2 to 3 times. This research also shows that living in a village that is in the forest has a high probability of contracting malaria (aOR 12.47) [2]. In Asia-Pacific, forest activities such as agriculture, logging, and gold mining at high risk for exposure to malaria. Workers in these forest areas tend to show patterns of mobility between endemic and non-endemic areas which can contribute to sustaining transmission and even lead to new cases of malaria that have previously been eliminated [31].

The forest ecosystem provides a suitable habitat for the development of the malaria mosquito vector. Environmental factors including climate, vegetation, and the availability of breeding places are important factors in malaria transmission. The mosquito species that is often found in the forest is Anopheles balabacencis. This species is the main vector of Plasmodium knowlesi transmission in Malaysian Borneo [32]. The study of Harbach in Sinka et al., showed that malaria vectors found in South Kalimantan are A. balabacencis and Anopheles leucosphyrus [33]. Research by Edward et al., In Central Viet Nam, the study shows that the most common species of Anopheles are Anopheles dirus, and Anopheles maculatus were captured as far as $4.5 \mathrm{~km}$ from forest area and farm [34]. In this research, researcher did not do identification of mosquito vector. 
The higher abundance of mosquitoes is one of the causes of ongoing infection in the forest [35]. Vector species and biting behavior are important factors in malaria transmission. In some areas, it has been shown that vector biting behavior in the late afternoon or early morning influences the incidence of malaria even though the use of bed nets is very high. Therefore, the main vector species with its characteristics and behavior in an area must be known so that prevention can be carried out appropriately and effectively. The habit of biting vectors such as indoors or outdoors, the time of biting, and their preference for animal or human blood will affect the transmission of malaria in an area [36], [37], [38].

The structure of the house has been proven to be one of the factors that facilitate the transmission of malaria [26], [27], [37]. The results of this study indicate that almost all residents own houses with wooden walls and tin roofs. Only a small proportion of the population has a plastic roof. The population who experienced malaria infection in this study had a partially open house. The malaria vector biting outdoors will freely enter this open house and obscure the indoor/outdoor bite difference. People are more easily exposed to mosquito bites if they live in a shack or temporary house where the walls are mostly open and the roof is not permanent [35]. A study in Vietnam showed that wooden or bamboo houses had a higher risk than permanent houses in the same village (odds ratio $4.18 \mathrm{Cl}$ : 1.45-12.10) [6]. It is easier for mosquitoes to enter houses with wooden or bamboo walls through open gaps. Arranging bamboo or wood in an overlapping or layered manner can reduce the possibility of mosquitoes entering the house. The use of insecticide-treated mosquito nets in the house that is not tight can reduce the bite of malaria vector [46]. Similar observations in Gambia and Ethiopia show that houses equipped with ceilings, and mosquito nets can reduce the density of mosquitoes inside the house [39], [40], [41].

Role of health officer in this location of research was finding case actively and passively. Active program used mass blood survey using RDT. Passive program was visiting patients in Teluk Kepayang Public Health Center and village health center in Batu Bulan and Batu Paha Village. Program of malaria intervention was done by giving insecticide kelambu and treatment of patient if they are possitive RDT.

The existence of cattle sheds around the house or inside the house is one of the risk factors for malaria transmission [42]. In this study, residents who had cattle sheds around their houses were more likely to be exposed to malaria $(O R=6.292)$ compared to residents who did not have cattle sheds. The livestock that kept in this village is chickens and goats with a cage distance from the house ranging from 2 to 3 meters. Having cattle sheds can lead to an increase in vector density around the house. This risk will increase if the cage is inside the house [43]. It shows that livestock can attract Anopheles, especially those that are zoophilic. The presence of livestock can also reduce Anopheles mosquito bites in the home, but not all studies support this result. The impact of livestock on malaria and vector density is complex. Some studies show that livestock provides zooprophilic protection while other studies show that livestock increases the risk of [44] [45].

The research of Hasyim et al. shows that there is a positive relationship between keeping animals in the house and the prevalence of malaria (AOR $=2.809$ ). The explanation for this result is that the presence of livestock attracts the population of mosquitoes that are vectors of plasmodium into the house, thereby increasing exposure to humans through zoopotentiation. Zoopotentiation can also occur if physical disturbance caused by animals (e.g., standing water, hoof prints, watering sites) increases the potential for larval habitat and therefore increases vector density near houses [42]. Increased abundance of goats or sheep has been shown to increase Anopheles mosquito abundances within a $20 \mathrm{~m}$ radius around Kenyan households. Each additional goat or sheep increases local malaria vector abundance [46].

\section{Conclusions}

This study provides evidence on factors that influence the high prevalence of malaria in remote forest areas in South Kalimantan. The factors that influence malaria are age, village, occupation, and the structure of the house. The influential factors of the house are the walls that are not tight/open, the roof made of plastic, and the presence of animal cages around the house. Intensive malaria management is needed to improve housing conditions, expansion of the use of insecticide mosquito nets, and treatment for asymptomatic and symptomatic patients. This intervention could have an enormous impact on the success of the national malaria elimination goals.

\section{References}

1. World Health Organization. World Malaria Report 2020 Geneva: World Health Organization; 2020. Available from: https://www.who.int/publications/i/item/9789240015791. [Last accessed on 2021 Jun 26].

2. Sandfort M, Vantaux A, Kim S, Obadia T, Pepey A, Gardais S, et al. Forest malaria in Cambodia: The occupational and spatial clustering of Plasmodium vivax and Plasmodium falciparum infection risk in a cross-sectional survey in Mondulkiri province, Cambodia. Malar J. 2020;19(1):1-12. https://doi.org/10.1186/ s12936-020-03482-4

3. Dhiman S. Are malaria elimination efforts on right track? 
An analysis of gains achieved and challenges ahead. Infect Dis Poverty. 2019;8(1):14. https://doi.org/10.1186/ s40249-019-0527-7

PMid:30760324

4. Ministry of Health of the Republic of Indonesia. Basic Health Research 2018. Jakarta: Ministry of Health of the Republic of Indonesia; 2018. https://doi.org/10.25133/jpssv27n1.003

5. Kar NP, Kumar A, Singh OP, Carlton JM, Nanda N. A review of malaria transmission dynamics in forest ecosystems. Parasit Vectors. 2014;7:265. https://doi.org/10.1186/1756-3305-7-265 PMid:24912923

6. Thanh PV, van Hong $\mathrm{N}$, van Van $\mathrm{N}$, van Malderen $\mathrm{C}$, Obsomer V, Rosanas-Urgell A, et al. Epidemiology of forest malaria in Central Vietnam: The hidden parasite reservoir. Malar J. 2015;14:86. https://doi.org/10.1186/s12936-015-0601-y PMid:25880664

7. Sanann N, Peto TJ, Tripura R, Callery JJ, Nguon C, Bui TM, et al. Forest work and its implications for malaria elimination: A qualitative study. Malar J. 2019;18(1):376.

PMid:31771587

8. Abiodun GJ, Maharaj R, Witbooi P, Okosun KO. Modelling the influence of temperature and rainfall on the population dynamics of Anopheles arabiensis. Malar J. 2016;15:364.

PMid:27421769

9. Fornace KM, Diaz AV, Lines J, Drakeley CJ. Achieving global malaria eradication in changing landscapes. Malar J. 2021;20(1):69.

PMid:33530995

10. Kunkel A, Nguon C, Iv S, Chhim S, Peov D, Kong P, Kim S, et al. Choosing interventions to eliminate forest malaria: Preliminary results of two operational research studies inside Cambodian forests. Malar J. 2021;20(1):51. PMid:33472630

11. Bauhoff $S$, Busch J. Does deforestation increase malaria prevalence? Evidence from satellite data and health surveys. World Dev. 2020;127:104734.

12. Lindblade KA, Walker ED, Onapa AW, Katungu J, Wilson ML. Land use change alters malaria transmission parameters by modifying temperature in a highland area of Uganda.Trop Med Int Health. 2000;5(4):263-74.

PMid:10810021

13. Patz JA, Graczyk TK, Geller N, Vittor AY. Effects of environmental change on emerging parasitic diseases. Int $\mathrm{J}$ Parasitol. 2000;30(12-13):1395-405.

PMid:11113264

14. Afrane YA, Lawson BW, Githeko AK, Yan G. Effects of microclimatic changes caused by land use and land cover on duration of gonotrophic cycles of Anopheles gambiae (Diptera: Culicidae) in Western Kenya Highlands. J Med Entomol. 2005;42(6):974-80. https://doi.org/10.1093/jmedent/42.6.974 PMid:16465737

15. Munga S, Minakawa N, Zhou G, Mushinzimana E, Barrack OO, Githeko AK, et al. Association between land cover and habitat productivity of malaria vectors in Western Kenyan Highlands. Am J Trop Med Hyg. 2006;74(1):69-75. https://doi.org/10.4269/ ajtmh.2006.74.69

PMid: 16407348

16. Zhong D, Wang X, Xu T, Zhou G, Wang Y, Lee MC, et al. Effects of microclimate condition changes due to land use and land cover changes on the survivorship of malaria vectors in ChinaMyanmar Border region. PLoS One. 2016;11(5):e0155301. https://doi.org/10.1371/journal.pone.0155301 PMid:27171475

17. Petney TN. Environmental, cultural and social changes and their influence on parasite infections. Int $\mathrm{J}$ Parasitol. 2001;31(9):919-32.

PMid:11406141

18. Vittor AY, Gilman RH, Tielsch J, Glass G, Shields T, Lozano WS, et al. The effect of deforestation on the human-biting rate of Anopheles darlingi, the primary vector of falciparum malaria in the Peruvian Amazon. Am J Trop Med Hyg. 2006;74(1):3-11. https://doi.org/10.4269/ajtmh.2006.74.3

PMid: 16407338

19. Schlabe S, Reiter-Owona I, Nordmann T, DolscheidPommerich R, Tannich E, Hoerauf A, et al. Rapid diagnostic test negative Plasmodium falciparum malaria in a traveller returning from Ethiopia. Malar J. 2021;20(1):145. https://doi.org/10.1186/ s12936-021-03678-2

PMid:33712017

20. World Health Organization. Malaria Rapid Diagnostic Test Performance: Results of WHO Product Testing of Malaria RDTs: Round 8 (2016-2018). Geneva: World Health Organization; 2018. https://doi.org/10.2471/tdr.09.978-924-1598071

21. World Health Organization. Malaria Microscopy, Quality Assurance Manual. Version 2. Geneva: World Health Organization; 2016.

22. Berzosa P, de Lucio A, Romay-Barja M, Herrador Z, González V, García L, et al. Comparison of three diagnostic methods (microscopy, RDT, and PCR) for the detection of malaria parasites in representative samples from Equatorial Guinea. Malar J. 2018;17(1):333. https://doi.org/10.1186/s12936-018-2481-4 PMid:30223852

23. Tanah Bumbu Regency Government. General Data of Kusan Hulu District. Indonesia: Tanah Bumbu Regency Government; 2020. Available from: http://www.kusanhulu.tanahbumbukab. go.id/?page_id=19 [Last accesed on 2021 Jan 04]. https://doi. org/10.17501/24246735.2018.4105

24. Murhandarwati EE, Fuad A, Sulistyawati $S$, Wijayanti MA, Bia MB, Widartono BS, et al. Change of strategy is required for malaria elimination: A case study in Purworejo District, Central Java Province, Indonesia. Malar J. 2015;14:318. https://doi. org/10.1186/s12936-015-0828-7

25. Raman J, Gast L, Balawanth R, Tessema S, Brooke B, Maharaj $R$, et al. High levels of imported asymptomatic malaria but limited local transmission in KwaZulu-Natal, a South African malaria-endemic province nearing malaria elimination. Malar J. 2020;19:152. https://doi.org/10.1186/s12936-020-03227-3

26. Mosha JF, Lukole E, Charlwood JD, Wright A, Rowland M, Bullock $O$, et al. Risk factors for malaria infection prevalence and household vector density between mass distribution campaigns of long-lasting insecticidal nets in North-Western Tanzania. Malar J. 2020;19:297. https://doi.org/10.1186/ s12936-020-03369-4

27. Chipoya MN, Shimaponda-Mataa NM. Prevalence, characteristics and risk factors of imported and local malaria cases in North-Western Province, Zambia: A cross-sectional study. Malar J. 2020;19(1):430. https://doi.org/10.1186/ s12936-020-03504-1

PMid:33228684

28. Achidi EA, Apinjoh TO, Anchang-Kimbi JK, Mugri RN, Ngwai AN, Yafi CN. Severe and uncomplicated falciparum malaria in children from three regions and three ethnic groups in Cameroon: Prospective study. Malar J. 2012;11:215. https://doi. org/10.1186/1475-2875-11-215 PMid:22727184

29. Alam MS, Kabir MM, Hossain MS, Naher S, Ferdous NE, Khan WA, et al. Reduction in malaria prevalence and increase in malaria awareness in endemic districts of Bangladesh. Malar J. 2016;15(1):552. https://doi.org/10.1186/s12936-016-1603-0 PMid:27836016 
30. Sulistyawati S, Fitriani I. Risk Factor and cluster analysis to identify malaria hot spot for control strategy in samigaluh sub-district, Kulon Progo, Indonesia.Iran J Public Health. 2019;48(9):1647-53. https://doi.org/10.18502/ijph.v48i9.3024 PMid:31700820

31. Ekawati LL, Johnson KC, Jacobson JO, Cueto CA, Zarlinda I, Elyazar IRF, et al. Defining malaria risks among forest workers in Aceh, Indonesia: A formative assessment. Malar J. 2020;19(1):441. https://doi.org/10.1186/s12936-020-03511-2 PMid:33256743

32. Rahim MA, Munajat MB, Idris ZM. Malaria distribution and performance of malaria diagnostic methods in Malaysia (19802019): A systematic review. Malar J. 2020;19(1):395. https://doi. org/10.1186/s12936-020-03470-8 PMid:33160393

33. Sinka ME, Bangs MJ, Manguin S, Chareonviriyaphap T, Patil AP, Temperley WH, et al. The dominant Anopheles vectors of human malaria in the Asia-Pacific region: Occurrence data, distribution maps and bionomic précis. Parasit Vectors. 2011;4:89. https:// doi.org/10.1186/1756-3305-4-89 PMid:21612587

34. Edwards HM, Chinh VD, Le Duy B, Thanh PV, Thang ND, Trang DM, et al. Characterising residual malaria transmission in forested areas with low coverage of core vector control in central Viet Nam. Parasit Vectors. 2019;12(1):454. https://doi. org/10.1186/s13071-019-3695-1

PMid:31533794

35. Edwards HM, Sriwichai P, Kirabittir K, Prachumsri J, Chavez IF, Hii J. Correction to: Transmission risk beyond the village: Entomological and human factors contributing to residual malaria transmission in an area approaching malaria elimination on the Thailand-Myanmar border. Malar J. 2019;18(1):248. https://doi.org/10.1186/s12936-019-2852-5

PMid:31340814

36. Tusting LS, Ippolito MM, Willey BA, Kleinschmidt I, Dorsey $G$, Gosling RD, et al. The evidence for improving housing to reduce malaria: A systematic review and meta-analysis. Malar J. 2015;14:209. https://doi.org/10.1186/s12936-015-0724-1 PMid:26055986

37. Tusting LS, Bottomley C, Gibson H, Kleinschmidt I, Tatem AJ, Lindsay SW, et al. Housing improvements and malaria risk in sub-Saharan Africa: A multi-country analysis of survey data. PLoS Med. 2017;14(2):e1002234. https://doi.org/10.1371/ journal.pmed.1002234

PMid:28222094

38. Ng'ang'a PN, Okoyo C, Mbogo C, Mutero CM. Evaluating effectiveness of screening house eaves as a potential intervention for reducing indoor vector densities and malaria prevalence in Nyabondo, Western Kenya. Malar J. 2020;19(1):341. https://doi. org/10.21203/rs.2.18504/v2

PMid:32950061

39. Kirby MJ, Green C, Milligan PM, Sismanidis C, Jasseh M, Conway $\mathrm{D}$, et al. Risk factors for house-entry by malaria vectors in a rural town and satellite villages in The Gambia. Malar J. 2008;7:2. https://doi.org/10.1186/1475-2875-7-2

PMid:18179686

40. Lindsay SW, Jawara M, Paine K, Pinder M, Walraven GE, Emerson PM. Changes in house design reduce exposure to malaria mosquitoes. Trop Med Int Health. 2003;8(6):512-7. https://doi.org/10.1046/j.1365-3156.2003.01059.x PMid:12791056

41. Massebo F, Lindtjørn B. The effect of screening doors and windows on indoor density of Anopheles arabiensis in SouthWest Ethiopia: A randomized trial. Malar J. 2013;12:319. https:// doi.org/10.1186/1475-2875-12-319 PMid:24028542

42. Hasyim H, Dhimal M, Bauer J, Montag D, Groneberg DA, Kuch $U$, Müller R. Does livestock protect from malaria or facilitate malaria prevalence? A cross-sectional study in endemic rural areas of Indonesia. Malar J. 2018;17(1):302. https://doi. org/10.1186/s12936-018-2447-6 PMid:30126462

43. Yamamoto SS, Louis VR, Sié A, Sauerborn R. The effects of zooprophylaxis and other mosquito control measures against malaria in Nouna, Burkina Faso. Malar J. 2009;8:283. https:// doi.org/10.1186/1475-2875-8-283 PMid:20003189

44. Idrees M, Jan AH. Failure of zooprophylaxis: Cattle ownership increase rather than reduce the prevalence of malaria in district dir, NWFP of Pakistan. J Med Sci. 2001;1:52-4. https://doi. org/10.3923/jms.2001.52.54

45. Mayagaya SV, Nkwengulila G, Lyimo NI, Kihonda J, Mtambala $\mathrm{H}$, Ngonyani $\mathrm{H}$, et al. The impact of livestock on the abundance, resting behaviour and sporozoite rate of malaria vectors in Southern Tanzania. Malar J. 2015;14:1-14. https:// doi.org/10.1186/s12936-014-0536-8

46. Iwashita H, Dida GO, Sonye GO, Sunahara T, Futami K, Njenga SM, et al. Push by a net, pull by a cow: Can zooprophylaxis enhance the impact of insecticide treated bed nets on malaria control? Parasit Vectors. 2014;7:52. https://doi. org/10.1186/1756-3305-7-52

PMid:24472517 